\title{
"Dumping" and the Competition Act of South Africa
}

\author{
Clive Vinti \\ $L L M$ \\ Lecturer, Department of Public Law, University of the Free State
}

\begin{abstract}
SUMMARY
The Competition Commission and the International Trade Administration Commission have concluded a Memorandum of Agreement to address matters of concurrent jurisdiction. However, the Memorandum of Agreement does not specify these areas of concurrent jurisdiction. Consequently, this paper seeks to assess the legal implications of this agreement with a specific focus on the correlation between "prohibited practices" under the Competition Act 89 of 1998 and "dumping" in the manner contemplated by the International Trade Administration Act 71 of 2002.
\end{abstract}

\section{Introduction}

"Dumping" refers to the introduction of a product into the market of another country at a price that is lower than their normal value. The World Trade Organization (WTO) has a fully-fledged legislative scheme to address dumping. This is achieved through the nexus of the General Agreement on Tariffs and Trade 1994 (GATT) and the Agreement on the Implementation of Article VI of the General Agreement on Tariffs and Trade 1994 (Anti-Dumping Agreement). There are two forms of "dumping": the first is "international price discrimination", which occurs through "price discrimination by the investigated producer between the domestic and export markets". 1 The second form is "cost dumping", which occurs when an exporter sells products in an importing country at below the cost of production. ${ }^{2}$ To give effect to South Africa's obligations on "dumping", South Africa has promulgated the International Trade Administration Act 71 of 2002 (ITAA); the Customs and Excise Act 91 of 1964; the Board on Tariffs and Trade Act 107 of 1986 and the International Trade Administration Commission Regulations on AntiDumping in South Africa (GN 3197 in GG 25684 of 14 November 2003 (Anti-Dumping Regulations). It follows from the definition of "dumping”,

1 World Trade Organization Panel Report, United States-Definitive Antidumping and countervailing duties on certain duties from China WT/DS379/R, adopted 25 March 2011, par 14.69; Bhala Modern GATT Law: A Treatise on the Law and Political Economy of the General Agreement on Tariffs and Trade and other World Trade Organisation Agreements (2013) 705.

2 Bhala 705.

How to cite: Vinti “"Dumping” and the Competition Act of South Africa' 2019 De Jure Law Journal 207-220 http://dx.doi.org/10.17159/2225-7160/2019/v52a13 
that a foreign firm can only commit this infraction. This dumping is penalized through the imposition of an anti-dumping duty. ${ }^{3}$

However, "international price discrimination" and "cost dumping" are also prohibited under the banner of "prohibited practices" in the Competition Act 89 of 1998 (the Act). In this regard, section 9 of the Act regulates "prohibited price discrimination" by "dominant firms". Similarly, it is regarded as a "prohibited practice" to engage in "predatory pricing" or "cost dumping", which is in essence, the selling of goods below their "cost of production". 4 In this way, the Act prohibits "international price discrimination" and "cost dumping" by foreign and domestic "dominant firms". Thus, a foreign "dominant firm", which has engaged in prohibited price discrimination or cost dumping, will have simultaneously violated the Act and the anti-dumping law of South Africa. This may mean that a foreign producer may face the unpalatable prospect of both an administrative penalty imposed by the Competition Tribunal and an anti-dumping duty from the International Trade Administration Commission (ITAC). This would constitute a "double remedy". The government of South Africa would in essence, be penalizing the same injury twice. This means that there is an overlap between the jurisdictions of ITAC and the Competition Commission. In a bid to address matters of concurrent jurisdiction and the possibility of a "double remedy", the Competition Commission and ITAC have concluded a Memorandum of Agreement. Consequently, this paper seeks to evaluate whether this Memorandum of Agreement addresses this "double remedy". This evaluation will be conducted through a detailed analysis of the relevant legislative scheme and case law.

To this end, this paper is divided into three parts: the first part of the paper establishes the conceptual overlap between competition law and anti-dumping law in South Africa; the second part evaluates the legal implications of the Memorandum of Agreement on the concurrent regulation of "prohibited price discrimination" and "cost dumping" and the final part of the paper offers a conclusion.

\section{The overlap between "dumping" and "prohibited practices"}

\section{1 "Dumping" in South African law}

South Africa is a founding member of the WTO and party to the Agreement Establishing the World Trade Organization 1994. ${ }^{5}$ The

3 S 56 of the Customs and Excise Act 91 of 1964.

4 S 8(d)(iv) of the Competition Act 89 of 1998 (hereafter, the Act); for a discussion on "prohibited practices", see Munyai "Claims for damages arising from conduct prohibited under the Competition Act, 1998" 2017 De Jure 18-35.

5 Association of Meat Importers $v$ ITAC (769, 770,771/12) 2013 ZASCA 108 par 10; Progress Office Machines v SARS 2007 SCA 118 (RSA) par 5. 
Agreement Establishing the World Trade Organization 1994 consists of several agreements including the GATT and the Anti-Dumping Agreement, which regulate the practice of "dumping". 6 South African acceded to the GATT and its accession was promulgated in the Government Gazette. ${ }^{7}$ Parliament endorsed the GATT in the Geneva General Agreement on Tariffs and Trade Act 29 of $1948 .^{8}$ Thus, South Africa's international obligations on "dumping" are borne out of the GATT and the Anti-Dumping Agreement. ${ }^{9}$ These obligations are complied with through domestic legislation, which consists of the ITAA, Customs and Excise Act, the Board on Tariffs and Trade Act and the AntiDumping Regulations. ${ }^{10}$

In this regard, "dumping" is defined as the introduction of goods into the market of another country at an export price that is less than the normal value of those goods. ${ }^{11}$ However, the GATT does not prohibit "dumping"; rather, the GATT "condemns" dumping. ${ }^{12}$ This "condemnation" is expressed in the form of an "anti-dumping duty". 13 The purpose of the "anti-dumping duty" is to "off-set or prevent dumping". ${ }^{14}$ This anti-dumping duty is calculated based on the "antidumping margin", which is the amount by which the normal value of a product exceeds its export price. ${ }^{15}$

To this end, there are two types of "dumping". The first form is "international price discrimination", which is the sale of goods in the

6 Association of Meat Importers $v$ ITAC supra, par 10; Progress Office Machines $\checkmark$ SARS supra, par 5 .

7 Progress Office Machines v SARS supra, par 5; GN 2421 of 18 November 1947.

8 Progress Office Machines v SARS supra, par 5.

9 International Trade Administration Commission $v$ SCAW South Africa (Pty) Ltd 20124 SA 618 (CC) par 2; Progress Office Machines v SARS supra, par 5; for a discussion of these judgments on this issue, see Vinti "A Spring without Water: The Conundrum of Anti-dumping Duties in South African Law" 2016 PELJ 19; Ndlovu "South Africa and the World Trade Organization Antidumping Agreement Nineteen Years into Democracy" 2013 SAPL 296; Brink "Progress Office Machines v South African Revenue Services [2007] SCA 118 (RSA)" 2008 De Jure 645; Satardien "South Africa's International Trade Laws and its "Guillotine" Clause" 2010 Manchester Journal of International Economic Law 54; Sucker "Approval of an International Treaty in Parliament: How Does Section 231(2) 'Bind the Republic'?” 2013 Constitutional Court Review 417-434.

10 International Trade Administration Commission v SCAW South Africa (Pty) Ltd supra, par 2.

11 S 1 of International Trade Administration Act 71 of 2002 (hereafter, ITAA) read with art 2(1) of the Agreement on the Implementation of Article VI of the General Agreement on Tariffs and Trade 1994 (hereafter, Anti-Dumping Agreement) and art VI.1 of the General Agreement on Tariffs and Trade 1994 (hereafter, GATT).

12 Art VI.1 of the GATT; Bhala 730.

13 Art VI.2 of the GATT.

14 Art VI.2 of the GATT.

$15 \mathrm{~S}$ 12(1) of the International Trade Administration Commission Regulations on Anti-Dumping in South Africa GN 3197 in GG 25684 dated 14 November 2003 (hereafter, Anti-Dumping Regulations); art VI.2 of the GATT. 
market of another country at a price that is below that of the same goods in the ordinary course of trade in the exporter's domestic market. ${ }^{16}$ In this regard, it has been held that "dumping" refers to "price discrimination" by the investigated producer between the domestic and export markets. ${ }^{17}$ Thus, increased price discrimination leads to a higher margin of dumping. ${ }^{18}$ The South African regulatory framework on "dumping" also regulates "price discrimination" which is defined as the situation whereby the goods imported into the domestic market are sold at prices that are less than in the exporting country. ${ }^{19}$ It is clear then, that "dumping" in the form of "international price discrimination", is regulated by South African law in line with its obligations under the GATT and the Anti-Dumping Agreement.

The second form is "cost dumping", which is the sale of goods in an export market at prices that are less than their "cost of production".20 The GATT and the Anti-Dumping Agreement regulate "cost dumping" in the instance that the margin of dumping of a product cannot be determined according to a proper comparison of the "normal value" and "export price". 21 This occurs when there are no sales of the same product in the ordinary course of trade in the domestic market of the exporting country or when, as a consequence of the specific market situation or the low volume of the sales in the domestic market of the exporting country, such sales do not allow a proper comparison, the margin of dumping will be determined according to the "cost of production in the country of origin plus a reasonable amount for administrative, selling and general costs and for profits". ${ }^{22}$ This is called the "Constructed Normal Value". 23 Similarly, in South Africa, "cost dumping" is also regulated by the ITAA.

16 Art VI.1 of the GATT; Osode "An assessment of the WTO: Consistency of the procedural aspects of South African anti-dumping law and practice" 2003 Penn State International Law Review 19; Bhala 705.

17 World Trade Organization Panel Report, United States-Definitive Antidumping and countervailing duties on certain duties from China supra, par 14.69; Bhala 705; Matsushita "Basic Principles of the WTO and the Role of Competition Policy" 2004 Washington University Global Studies Law Review 371; Brink "Anti-Dumping in South Africa" (2012) 21 available at http:// www.tralac.org/files/2012/07/D12WP072012-Brink-Anti-Dumping-in-SA-201 20725final.pdf (accessed 2019-04-02); International Trade Administration Commission "Trade Remedies" available at http://www.itac.org.za/pages/ services/trade-remedies (accessed 2019-04-02).

18 World Trade Organization, United States-Definitive Anti-dumping and Countervailing Duties on Certain Products supra, par 568.

$19 \mathrm{~S} 1$ of the ITAA; Farm Frites International $v$ International Trade Administration Commission (unreported) case number 32263/14 of 20 May 2014 par 3.

20 Osode 2003 Penn State International Law Review 19; Bhala 705.

21 S 32(2)(b)(ii) of the ITAA, "export price" in essence, is defined as the "price actually paid or payable for goods sold for export, net of all taxes, discounts and rebates actually granted and directly related to that sale" whereas "normal value" in essence, defined as the "comparable price paid or payable in the ordinary course of trade for like goods intended for consumption in the exporting country or country of origin".

22 Art 2(2) of the Anti-Dumping Agreement read with art VI.1 (b) of the GATT.

23 Bhala 723. 
According to the ITAA, the determination of the "normal value" of goods may in certain instances, refer to the "constructed cost of production" of the goods in the country of origin when they are to be sold in the domestic market, plus a logical incorporation for selling, general and administrative costs and for profit. $^{24}$ It is clear then, that the determination of the margin of dumping using the "cost of production" is only used as an exception. ${ }^{25}$ This explains why "dumping" is seen as "generally" referring to "international price discrimination". Regardless, it is clear that South African law prohibits "international price discrimination" and "cost dumping" or "predatory pricing". This means that the South African law on dumping prohibits both forms of "dumping".

\section{2 "Prohibited Practices" under the Act}

One of the objects of the Act is to prevent anti-competitive trade practices. $^{26}$ The Act does this by prohibiting certain conduct that it deems a "prohibited practice". A "prohibited practice" is defined as a practice prohibited under Chapter 2 of this Act. One of the "prohibited practices" under Chapter 2 of the Act is "prohibited price discrimination". According to section 9 of the Act, a "dominant firm" can only commit "prohibited price discrimination". In simple terms, a "firm" includes "a person, partnership or trust". 27 The term "includes" means that the Act leaves the door open for other legal entities to qualify as a "firm". It must be noted now, that the Act does not distinguish between domestic and foreign firms. In fact, one of the objects of the Act is to acknowledge the role of foreign competition in South Africa. ${ }^{28}$

In turn, a firm is regarded as a "dominant firm" in a market, if it has acquired at least $45 \%$ of that market or it has at least $35 \%$, but less than $45 \%$, of that market, unless it can show that it does not have market power; or it has less than $35 \%$ of that market, but has market power. ${ }^{29}$ In this regard, "market power" refers to the power of a firm to influence prices, to impede competition or to behave to a considerable extent, independently of its competitors, customers or suppliers. ${ }^{30}$ Having established that a "dominant firm", which can be a domestic or foreign firm, can only commit "prohibited price discrimination" the Act then outlines the requirements for one's conduct to qualify as "prohibited price discrimination”.

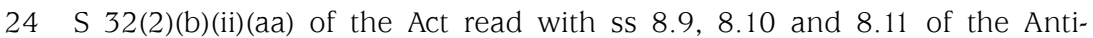
Dumping Regulations.

25 S 8 of the Anti-Dumping Regulations read with s 32(b)(ii) and s 32(6) ITAA, read with $\mathrm{s} 10$ of the Anti-Dumping Regulations.

26 Preamble to the Act.

27 S 1 of the Act.

28 S 2(d) of the Act.

29 S 7 of the Act.

$30 \mathrm{~S} 1$ of the Act. 
According to section 9 of the Act, there are three requirements for "prohibited price discrimination": first, it must be the conduct of a dominant firm as the seller of goods and services, which is likely to have the impact of materially preventing or reducing the competition, ${ }^{31}$ or in the alternative, where the conduct of a dominant firm will prevent the ability to participate effectively, of small and medium enterprises controlled or owned by historically disadvantaged persons; ${ }^{32}$ second, it must be connected to the sale in equivalent transactions, of goods and services of like quality and grade to different buyers and third, if it involves discriminating between those buyers in terms of inter alia, the purchase price for the goods or services; any discount, allowance or rebate allowed in relation to the supply of goods or services. ${ }^{33}$ These requirements are cumulative and thus an allegation of "prohibited price discrimination" must comply with these three requirements. ${ }^{34}$ It must be noted that it will now also be "prohibited price discrimination" for a dominant firm to prevent the selling of goods or services to a purchaser that is a small and medium business or a firm controlled or owned by historically disadvantaged persons in order to evade the operation of section 9(1)(a)(ii) of the Act. ${ }^{35}$ As already stated, section 9(1)(a)(ii) of the Act regulates the conduct of a dominant firm that is preventing the ability to participate effectively, of small and medium enterprises controlled or owned by historically disadvantaged persons.

However, there are exceptions to the rule on "prohibited price discrimination". According to section 9(2) of the Act, conduct which would be otherwise deemed "prohibited price discrimination" would nevertheless be lawful if it permits only "reasonable" accommodation for differentiation on cost or likely cost of manufacture, distribution, sale or promotion; second, the Act does not see it as "prohibited price discrimination" if the "differential treatment" consists of acts in "good faith" to mirror a price or advantage that is offered by a competitor and third, it is not "prohibited price discrimination" if the "different treatment" is a response to changing circumstances that are affecting the sale of the goods or services including inter alia: any action in response to the actual or impending decay of perishable goods and a sale for the purpose of insolvency proceedings. ${ }^{36}$ These exceptions give meaning to the term "prohibited price discrimination", which immediately implies that there are instances where "price discrimination" is lawful and thus, not "prohibited".

31 S 9(1)(a) of the Act.

32 S 6(b) of the Competition Amendment Act 18 of 2018, which has been assented to, by the President but will come into effect once it is proclaimed.

33 S 9(1)(c) of the Act; see Neuhoff A Practical Guide to the South African Competition Act (2006) 134-143; Mankga "When is price discrimination prohibited as anti-competitive?" 2007 Juta's Business Law 96-97.

34 Sasol Oil (Pty) Ltd v Nationwide Poles CC 20063 SA 400 (CAC) 15.

35 S 6(c) of the Competition Amendment Act 18 of 2018.

36 S 9(2) of the Act; see Sasol Oil (Pty) Ltd v Nationwide Poles CC supra, 15. 
Another "prohibited practice" under Chapter 2 of the Act is "cost dumping" or "predatory pricing". According to the Act, it is prohibited for a dominant firm to sell products "below their marginal or average variable cost". 37 "Marginal costs" refers to the price that is imposed for a product that is less than the cost of producing the last unit of it. ${ }^{38}$ In other words, "marginal cost" refers to the increase to total cost because of producing an additional unit of output. ${ }^{39}$ However, the term "average variable cost" is not defined in the Act. The yet to be promulgated amendment to the Act defines "average variable cost" as the total of all the costs that vary with an identified quantity of a particular product, divided by the total produced quantity of that product. ${ }^{40}$ The resort to "average variable cost" is based on the submission that "marginal costs" are difficult to ascertain. ${ }^{41}$ Thus, it has been held that the Act stipulates that there are two tests, which may be used to establish the existence of predatory pricing, namely a cost standard of marginal costs and of average variable cost. ${ }^{42}$

In this regard, the Competition Amendment Act adds that it is prohibited for a dominant firm to sell goods at "predatory prices". 43 "Predatory pricing" is defined as the selling of goods or services below the firm's average avoidable cost or average variable cost. ${ }^{44}$ "Average avoidable cost" means the total of all costs, including variable costs and product-specific fixed costs, that could have been avoided if the firm halted producing a specific amount of additional output, divided by the quantity of the additional output. ${ }^{45}$ It has been held that "average avoidable cost" is an alternative principle that encapsulates the cost the firm could have avoided by not embarking on a predatory strategy. ${ }^{46}$ The significant difference with "average variable cost", is that the "average avoidable cost" incorporates the factor of fixed costs, known as product specific fixed costs, thus making the fixed/variable conundrum more acceptable. ${ }^{47}$ In simple terms, the Competition Amendment Act adds the standard of "average avoidable cost" in the determination of the "cost of production". The inclusion of these traditional economic standards is significant because the failure of a dominant firm to cover its average avoidable cost or average variable cost implies that the dominant firm is deliberately losing profits in the interim, and therefore, may be engaged

\footnotetext{
37 S 8 (d)(iv) of the Act.

38 Competition Commission v Media 24 (Pty) Ltd 20162 CPLR 968 (CT) par 78.

39 Neuhoff 123.

40 S 1 (a) of the Competition Amendment Act 18 of 2018.

41 Competition Commission v Media 24 (Pty) Ltd supra, par 79.

42 Media 24 Proprietary Limited $v$ Competition Commission of South Africa 2018 4 SA 278 (CAC) par 45; see s 8(d)(iv) of the Act.

43 S 5 of the Competition Amendment Act 18 of 2018.

44 S 1 (i) of the Competition Amendment Act 18 of 2018.

45 S 1 (a) of the Competition Amendment Act 18 of 2018.

46 Competition Commission v Media 24 (Pty) Ltd supra, par 84.

47 Competition Commission v Media 24 (Pty) Ltd supra, par 84.
} 
in "exclusionary" conduct. ${ }^{48}$ It is clear then, that "marginal cost", "average avoidable cost" and "average variable cost", are methods used to determine the "costs of production". None of these methods is perfect and the courts have to be practical and choose the test, which may be better suited to resolve the dispute. ${ }^{49}$ It must be noted that section $8(1)(d)$ is not the only provision in the Act that regulates predatory pricing. ${ }^{50}$ Overall, there is no question that the Act prohibits the selling of goods below their "cost of production". This is the essence of "cost dumping". Consequently, there is no doubt that the Act prohibits "international price discrimination" and "predatory pricing" or "cost dumping". This means that the Act prohibits both forms of "dumping", which are deemed "prohibited practices" under the Act.

If a foreign dominant firm is found to have committed the act of "prohibited price discrimination" or "predatory pricing/cost dumping", then the Competition Tribunal can impose a variety of orders including an administrative penalty. ${ }^{51}$ This "administrative penalty" or "fine" may not be more than 10 per cent of the firm's annual turnover in South Africa and its exports from the Republic during the firm's preceding financial year. ${ }^{52}$ However, the administrative penalty can be more than 10 percent but not more than 25 percent of the offending firm's annual turnover in the Republic and its exports from the Republic during the firm is preceding financial year, if such firm is a repeat offender of the "prohibited practice" provisions. ${ }^{53}$ This "fine" or "administrative penalty" should be paid into the National Revenue Fund. ${ }^{54}$

It is then conceivable that a foreign dominant firm could be investigated for "international price discrimination" or "cost dumping" by both the ITAC and the Competition Commission. This could result in the concurrent imposition of an anti-dumping duty and an administrative penalty. ${ }^{55}$ To this end, Vinti, ${ }^{56}$ has postulated that the concurrent

48 Memorandum on the Objects of the Competition Amendment Bill, 2018 par 3.3.4; for further discussion on "exclusionary conduct", see Munyai "The lack of an appropriate causation framework in competition law proceedings under the Competition Act, 1998" 2017 Obiter 486-489.

49 Competition Commission v Media 24 (Pty) Ltd supra, par 96.

50 Nationwide Airlines (Pty) Ltd v SAA (Pty) Ltd 1999-2000 CPLR 230 (CT) 10; Competition Commission v Media 24 (Pty) Ltd supra, par 100; see s 8(c) of the Act.

51 S 58 read with s 59(1)(b) of the Act.

52 S 59(2) of the Act.

53 S 33(c) of the Competition Amendment Act 18 of 2018

54 S 59(4) of the Act.

55 Ss 58 and 59 of the Act; s 32(3) of the ITAA read with s 52 of the AntiDumping Regulations and ss 55 and 56(1) of the Customs and Excise Act 91 of 1964.

56 Vinti "A Critical Analysis of the Frozen Potato Chips Saga Between the Southern African Customs Union and Belgium and the Netherlands" 2017 Speculum Juris 156-157; art VI.5 of the GATT; World Trade Organization Panel Report, United States Definitive Anti-Dumping and Countervailing Duties on Certain Products from China supra, par 14.171 and footnote 1083; Wheatland Tube Co. v United States 495 F.3d 1355 (Fed. Cir. 2007) 10-17. 
imposition of anti-dumping and safeguard duties, could in certain instances, constitutes a "double remedy" that is prohibited by the GATT. According to Vinti, ${ }^{57}$ this concurrent imposition of these duties is a "double remedy" because it corrects the same injury twice. On the back of this hypothesis, it is my view that the concurrent imposition of an administrative fine and an anti-dumping duty as penalties for prohibited price discrimination or cost dumping against a foreign dominant firm, would also result in a "double remedy". The Competition Commission and ITAC have recognised the potential "double remedy" conundrum by concluding a Memorandum of Agreement (MOA).

\section{Assessment of the legal implications of the MOA}

The MOA seeks to facilitate cooperation and harmony between the Competition Commission and ITAC on matters of concurrent interest to give effect to their respective enabling legislation. ${ }^{58}$ This MOA has a sound legal basis. According to section 21(1)(h) of the Act, the Competition Commission has the authority to negotiate agreements with any regulatory body to organise and align the exercise of jurisdiction over competition issues within the relevant industry or sector, and to ensure the proper implementation of the provisions of this Act. In tandem with this provision, section 82(1) of the Act provides that a regulatory body which has the power in respect of conduct regulated in terms of Chapter 2 or 3 within a particular sector, to negotiate agreements with the Competition Commission, as contemplated in section 21(1)(h) and in respect of a particular matter within its jurisdiction, may exercise its jurisdiction by way of such an agreement. Thus, the Act empowers the Competition Commission and the ITAC to negotiate the MOA on matters that fall under Chapter 2 of the Act, which includes "prohibited price discrimination" and "cost dumping".

Furthermore, the Act provides that to the extent that this Act applies to an industry, which is subject to the authority of another regulatory body, which body has jurisdiction in respect of conduct regulated in terms of Chapter 2 or 3 of this Act, this Act must be read as conferring concurrent jurisdiction in respect of that conduct. ${ }^{59}$ This concurrent jurisdiction as exercised in terms of this Act and any other legislation, must be regulated, to the extent possible, in line with any applicable agreement concluded in terms of sections $21(1)(\mathrm{h})$ and 82(1) and (2). ${ }^{60}$ This means that the Competition Commission and ITAC, as regulatory

\section{Vinti 2017 Speculum Juris 156-157.}

58 Memorandum of Agreement Between the Competition Commission of South Africa and the International Trade Administration Commission of South Africa 2015 (hereafter, MOA) par 2 available at http://www.comp com.co.za/wp-content/uploads/2016/05/MoU-between-the-Competition-

Commission-and-ITAC.pdf (accessed 2018-12-09).

59 S 3(1A)(a) of the Act.

$60 \mathrm{~S} 3(1 \mathrm{~A})(\mathrm{b})$ of the Act. 
authorities that regulate the anti-competitive conduct of foreign firms, are bestowed with concurrent jurisdiction over matters such as "prohibited price discrimination" and "cost dumping", which are regulated by Chapter 2 of the Act and this jurisdiction must be implemented according to the MOA.

In the MOA, the Competition Commission and ITAC agree inter alia, to provide comment and advice on complaints and applications. ${ }^{61}$ This requires the parties to the "extent feasible": to make representations to each other; to refer complaints/applications falling within the jurisdiction of the other within a rational time after considering of such and to advice and receive advice from each other on matters of mutual interest. ${ }^{62}$ More specifically, the MOA permits the submission of representations to each other on matters that have international trade law or competition law "considerations". ${ }^{63}$ In this way, the MOA must be commended for promoting cooperative government as required by the Constitution and facilitating the sharing of valuable information and insights between government officials who share mutual expertise. ${ }^{64}$ However, this obligation to "refer" a matter is restricted by the proviso that this must be to the "extent feasible". ${ }^{65}$ This implies that ITAC and the Competition Commission have the discretion to transfer a matter to each other only if it is possible. Unfortunately, there are no precise guidelines on how this determination will be made. This leaves the offending firm unaware of which body will investigate them and which penalty they should expect. This also means that the offending firm will not know which law is applicable to the matter. In short, the MOA breeds uncertainty.

In the same breath, while the MOA purports to prevent the occurrence of the "double remedy", it does not actually do so. This is because the MOA does not stipulate that ITAC and the Competition Commission must always "refer" a matter to each other. Rather the MOA gives ITAC and the Competition Commission, the discretion to decide when to refer a matter because they must do so only if it is possible to do so. ${ }^{66}$ However, in instances whereby ITAC or Competition Commission are not aware of the "concurrent" considerations, these two investigative bodies would neither "refer" nor make any "representations" to each other in this regard. This would be problematic in several respects. First, this could mean that a foreign dominant firm could be liable to parallel investigations and a penalty from both investigative bodies. This could lead to a "double remedy" because it would penalize the same injury twice. Second, this invariably means that the offending foreign firm would have to defend parallel investigations. This unnecessarily encumbers the foreign firm and imposes a huge financial burden. Third, concurrent investigations, regardless of their duration, would waste

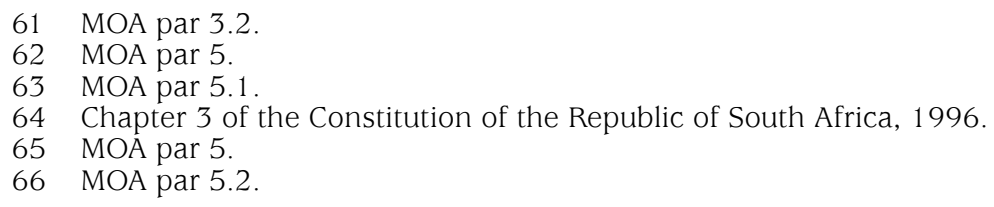


government resources and promote inefficiency. Fourth, the concurrent jurisdiction could actually facilitate "forum shopping" by aggrieved parties in the South African market. In essence, "forum shopping" would permit an aggrieved domestic firm to choose an adjudicatory body that it deems favourable to its case. ${ }^{67}$

However, the problem with forum shopping in this regard could be in the penalties that are imposed depending on whether the matter is addressed through either the Act or the Anti-dumping law of South Africa. On the one hand, the Act could require the imposition of a penalty up to $10 \%$ of the firm's annual turnover in the Republic and its exports from the Republic during the firm is preceding financial year. ${ }^{68}$ This means that the administrative penalty is capped at $10 \%$, which implies that the penalty could be less than the $10 \%$ threshold. However, this is not a purely mathematical process because the Act provides that the calculation of the administrative penalty must afford due consideration to factors such as the conduct of the respondent, the market circumstances in which the contravention took place and the extent to which the respondent has cooperated with the Competition Commission and the Competition Tribunal. ${ }^{69}$ This multi-faceted approach must be commended in that it allows for a variation of the penalty if the offender has cooperated with the Competition Commission. However, because the calculation of the administrative penalty is a discretionary process that is guided by an imprecise threshold i.e. the $10 \%$ cap, and nonmathematical factors such as "conduct" and "cooperation", it means that the offending foreign dominant firm would be unable to establish or predict the amount of the administrative penalty for prohibited conduct. This is in contrast to the anti-dumping margin, which is calculated according to the injury suffered, taking into consideration, adjustments that have been made for comparative purposes. ${ }^{70}$ Thus, the antidumping duty is more susceptible to precise determination whereas the administrative penalty is difficult to predict because it accords substantial discretion on the amount of the penalty. It follows that the aggrieved domestic firm could pursue the unpredictable avenue of the Act, instead of the ITAA, when it has a dispute with a foreign firm.

67 Whytock "The Evolving Forum Shopping System” 2011 Cornell Law Review 485; Clermont and Eisenberg "Exorcising the Evil of Forum-Shopping" 1994-1995 Cornell Law Review 1507-1535; Maloy "Forum Shopping What's Wrong with That" 2005 Quinnipiac Law Review 28; for a contrary view on "forum shopping", see Bookman "The Unsung Virtues of Global Forum Shopping" 2017 Notre Dame Law Review 579-636.

68 S 59(2) of the Act; s 33(c) of the Competition Amendment Act 18 of 2018, which provides that the administrative penalty may exceed $10 \%$ but not exceed 25 per cent of the firm's annual turnover in the Republic and its exports from the Republic during the firm's previous financial year if the conduct is in essence, a repeat by the same firm of conduct previously established by the Competition Tribunal to be a "prohibited practice".

69 S 59(3) of the Act.

70 S 1 of the Anti-Dumping Regulations, on definition of "margin of dumping" read with s 11 of the Anti-Dumping Regulations, which lists "adjustments" such as taxation and levels of trade. 
Overall, it is my view that since the Competition Commission and the ITAC had already done the difficult task of identifying the potential concurrent jurisdiction, it is disappointing that they have not completed the process of explicitly specifying the areas of concurrent competence. Consequently, it is my view that the MOA should be amended or that a provision be inserted into either the ITAA or the Act, which specifies that either investigative body will be charged with the investigation and imposition of a penalty/duty on a specific matter of concurrent competence. This would provide the necessary legal certainty that is required. Consequently, it my suggestion that the ambit of the Act must be narrowed to only regulate "prohibited price discrimination" and "predatory pricing" by domestic producers. The foreign dominant firms are already liable to the "prohibited price discrimination" and "cost dumping" regulation under the banner of anti-dumping law through the ITAA, Customs and Excise Act and the Anti-Dumping regulations. In simple terms, the Act's prohibition on price discrimination and cost dumping, as far as it relates to foreign firms, is superfluous. This submission is analogically based on the contention that anti-dumping laws are "redundant" if a country already has competition law legislation that addresses "prohibited price discrimination" and "cost dumping". 71 The converse is true that competition law legislation that regulates "prohibited price discrimination" and "predatory pricing" is "redundant" in respect of foreign firms, if there are anti-dumping laws that regulate prohibited price discrimination and cost dumping.

To the contrary, other commentators argue that there is no problem with this concurrent regulation of "prohibited price discrimination" and "cost dumping" because this situation offers "alternatives" to aggrieved parties. ${ }^{72}$ This submission is unsustainable. Apart from the fact that concurrent investigations could promote "forum shopping", the concurrent regulation of "prohibited price discrimination" and "cost dumping" by foreign dominant firms through competition law legislation and anti-dumping legislation, contravenes the national treatment clause of Article III of the GATT. ${ }^{73}$ That is to say, anti-dumping law does not apply to domestic firms i.e. a domestic company committing prohibited price discrimination or cost dumping only in the domestic market would only contravene competition law, but not the anti-dumping law. ${ }^{74}$ This then means that the concurrent regulation of "prohibited price discrimination" and "cost dumping" by foreign dominant firms in South African law, contravenes Article III of the GATT. ${ }^{75}$ Article III of the GATT

71 Bhala 710; Cooper “The Antidumping Act. Tariff or Antitrust Law?" 1965 Yale Law Journal 723; Coudert "The Application of the United States Antidumping Law in the Light of a Liberal Trade Policy" 1965 Columbia Law Review 189-231.

72 Bhala 710.

73 Bhala 710.

74 Bhala 710.

75 Bhala 710; see World Trade Organization Appellate Body Report, Japan Taxes on Alcoholic Beverages II, WT/DS8/AB/R; WT/DS10/AB/R; WT/DS11/AB/ $\mathrm{R}$, adopted 1 November 1996, 16. 
provides that the goods of the territory of any contracting party imported into the commerce of any other contracting party must not be liable, directly or indirectly, to internal taxes or other internal charges of any kind in excess of those imposed, directly or indirectly, to like domestic products. ${ }^{76}$ The import of Article III of the GATT is that the contracting parties must ensure "equality of competitive conditions for imported products in relation to domestic products". 77 In this way, the drafters of the GATT sought to accord the same treatment to imported products as that afforded to like domestic products once they enter the domestic market. ${ }^{78}$ Consequently, the MOA and the Act, by providing for concurrent regulation of "prohibited price discrimination" and "cost dumping" by a foreign firm, may impede the "equality of competitive conditions for imported products in relation to domestic products", which contravenes the national treatment clause in Article III of the GATT. It follows then that the MOA could be regarded as a protectionist measure, which violates the import of Article III of the GATT. ${ }^{79}$

A preferable approach would be that which is employed by the environmental legislation in South Africa. Faced with a fragmented approach that resulted in environmental harm by mining corporations, the government of South Africa decided to create an integrated system through an agreement between the departments of mineral resources, environmental affairs and water and sanitation. This MOA resulted in the creation of the One Environmental System (OES), which was incorporated into the National Environmental Management Act 107 of 1998 (NEMA), the framework legislation. ${ }^{80}$ The OES seeks to align the laws and policies of the portfolios of environmental affairs, mineral resources and water and sanitation. This has resulted in a legal framework that clearly specifies the powers of each relevant government department on matters of concurrent jurisdiction. ${ }^{81}$ Despite its challenges, the OES leaves no room for conjecture. ${ }^{82}$ It is then suggested that either the ITAA or the Act, be amended in the same manner as the NEMA to ensure legal certainty.

76 Art III.2 of the GATT.

77 World Trade Organization Appellate Body Report, Japan - Taxes on Alcoholic Beverages II supra, 16.

78 World Trade Organization Appellate Body Report, Japan - Taxes on Alcoholic Beverages II supra, 16.

79 See World Trade Organization Appellate Body Report, Japan - Taxes on Alcoholic Beverages II supra, 16.

80 S 50A(2) of National Environmental Management Act; s 38A(1) of the Mineral and Petroleum of Resources and Development Act 28 of 2002; National Environmental Management Amendment Act 62 of 2008; National Environmental Laws Amendment Act 25 of 2014; Environmental Impact Assessment Regulations and Listing Notices, 2014; National Appeal Regulations, 2014; National Exemption Regulations, 2014.

81 S 50A of the National Environmental Management Act.

82 Vinti "The power to declare a prohibition or restriction on prospecting or mining to protect the environment: a critical assessment of s 49 of the Mineral and Petroleum Resources Development Act 28 of 2002 and s 24(2A) of the National Environmental Management Act 107 of 1998" 2018 Journal of Energy \& Natural Resources Law 16. 


\section{Conclusion}

The Act and the anti-dumping legislation regulate "prohibited price discrimination" and "cost dumping" by a foreign dominant firm. This means that there is an overlap between these two sets of legislation and in the functions of ITAC and the Competition Commission. This could result in the concurrent imposition of an administrative penalty and an anti-dumping duty on a foreign dominant firm. To address this conundrum, the ITAC and the Competition Commission have concluded an MOA. This paper then sought to assess the efficacy of this MOA. On this score, this paper finds that the MOA breeds uncertainty, as it does not actually address the matters of concurrent jurisdiction. This is because the ITAC and the Competition Commission have the discretion to refer or to make representations to each other on matters of concurrent considerations, if it possible to do so. However, the MOA does not actually specify the matters of concurrent jurisdiction. In this paper, I suggested matters of concurrent jurisdiction between the Act and antidumping law in South Africa; it is possible that there are other matters of concurrent "consideration", which the MOA should have explicitly specified.

Unfortunately, in the event that the ITAC and the Competition Commission are unaware that a specific matter is a concurrent "consideration", then it is possible that parallel investigations and the concurrent imposition of an anti-dumping duty and an administrative penalty, could occur. It is my view that this would be tantamount to a "double remedy" because it addresses the same injury twice. This would discourage foreign investment. In the same breath, the institution of parallel investigations would waste crucial government resources and promote "forum shopping".

Even more significant, the concurrent regulation of "prohibited price discrimination" and "cost dumping" by a foreign dominant firm, contravenes the national treatment clause of Article III of the GATT. It is thus my view that the MOA could be seen as a protectionist measure that violates the objects of the GATT. Consequently, it is my recommendation that the MOA could be amended to expressly specify the matters of concurrent jurisdiction and to specify which investigative body has authority in each matter. It is then my view that the MOA could be amended in the same manner as the OES, which offers a clear and pragmatic demarcation of matters of concurrent jurisdiction between the relevant government departments. 